\title{
Kurdistan Parliament: Formation of A De Jure Institution in a De Facto
}

\section{State}

Mohammedali Yaseen Taha 1,2, Angela Movileanu ${ }^{3}$

${ }^{1}$ Department of Political Science, Nawroz University, Duhok, Kurdistan Region, Iraq 2Universidade de Lisboa, Instituto de Ciências Sociais, Av. Professor Aníbal de Bettencourt, 9, LISBOA, Portugal ${ }^{3}$ Research Associate, CEI, IUL, Centro de Estudos Internacionais, ISCTE-Instituto Universitario De Lisboa, Portugal

\begin{abstract}
The Kurdistan Parliament - Iraq was established in 1992 and has increasingly gained legitimacy both inside and outside the region. The parliament is a unicameral legislative body in the northern part of Iraq recognized as a federal region officially known as Kurdistan Region of Iraq (KRI). It has been functioning as a de jure institution in a de facto state, with a reasonably stable legislative capacity. The formalized procedures and legally established functions of this parliament are indicative of a functional institution, albeit with long periods in which the main parliamentary parties do not reach the required consensus to legislate. After five election cycles, five parliamentary terms and having passed hundreds of laws, are the region and its representative institution able to pass the test of being a minimal democracy?
\end{abstract}

\section{Introduction}

This paper delves into the existing legal bases and formal provisions that regulate the parliament of the Kurdistan Region of Iraq (KRI). Firstly, the background of the parliament will be described from the perspective of its recent history and constitutional attempts to legalize this emergent institution. Then, general consideration is given to the elections and party composition during the successive parliamentary terms since the establishment of the parliament in 1992. After this, descriptions of the formal structure, functions and powers of the Kurdistan Parliament - Iraq, along with its relationship with other institutional bodies, are provided. The article also describes its internal dynamics and functional mechanisms, as well as the role of fractions and committees, subsequently offering insights into the legislative process and legislative production. Given the absence hitherto of research regarding the Kurdistan Parliament-Iraq, this article constitutes an initial attempt to provide a rather broad outline of the existence of the institution, the unfolding of the inherent formal arrangements and functions of the parliament. Large gaps urgently need to be addressed by further research, adopting quantitative data and placing it alongside relevant case studies regarding such institutions, employing mainstream comparative methodology.

\section{Legal Bases of the Kurdistan Parliament-Iraq}

The Kurdistan Parliament, along with the other political institutions of the region, functions within the context of the Iraqi constitution, along with other regulatory and provisional laws established by the emergent regional institutions of the KRI since the inception of the autonomous government there. This autonomy was generally considered to constitute a de facto state until the fall of the Baath regime and continued to be recognized as legitimate from 2005 to the present day. The autonomous government of the KRI was established in 1992, and the establishment of the Kurdistan National Assembly was among the first acts of institutionalization by the autonomous government. The region's Law No. 1 (Kurdistan Parliament, 1992; Kurdistan National Assembly, 1992), which instituted the one chamber parliament elected 
by direct vote every four years, was inspired by existing consolidated democracies. Later, in 2009, the name of the parliament was changed from Kurdistan National Assembly to Kurdistan Parliament-Iraq through an amendment to the bylaw concerning the parliament (Kurdistan Parliament, 2009).

After the US led coalition removed the Baath party from power in Iraq, the Kurds, as one of the main opposition groups, took part in building a new Iraq alongside other Iraqi entities. An interim government was appointed in Iraq composed of the representatives of different Iraqi ethnic and religious groups, ${ }^{i}$ and these participated in the committee that drafted the Iraqi Constitution, which was ratified in 2005. ${ }^{\text {ii }}$ In accordance with this, the Kurdistan Parliament-Iraq has the authority to legislate as a regional parliament on a large range of issues, on condition that these do not contradict the Iraqi Constitution itself. iii Legislation by the federal parliament can be enacted, amended or not adopted by the KRI and priority is given to the laws legislated by the Kurdistan Parliament-Iraq. The Iraqi Constitution recognizes, among others, that the region of Kurdistan has the right to exercise legislative powers. In case of a contradiction between regional and national legislation in respect to a matter outside the exclusive authorities of the federal government, the regional power has the right to amend the application of the national legislation within the region. Furthermore, the 2005 Constitution recognizes laws enacted in the region of Kurdistan after 1992, "[p]rovided that they do not contradict the Constitution" (Constitute Project, 2021).

After more than two decades, the Kurdistan Parliament-Iraq is in continuous evolution in both structure and content. This is an ongoing reshaping process to adjust itself and accommodate internal factors deriving from manifest ambitions for independence and breakaway from the central government, modest democratic aspirations, regional security and economic issues, local cultures, continuing internal struggles and the need for political elites to be better educated about their roles.

The most noteable characteristic of the KRI's political system is the absence of a constitution that would regulate it in the classic sense. The draft Kurdistan Constitution was finalized in 2009 but, due to various disagreements among the political parties, a new committee for redrafting was established in 2015. This committee consisted of 21 members intended to represent the diversity of the region, but in fact the choice of committee members and who they represented was fully politicized. The committee was granted a period of 90 days to finalize the draft but due to disagreements between the main parties it stopped work shortly after its creation. As well as the intragroup misunderstandings, there is no great pressure for this constitution to come into being, because any such constitution would expose ambitions for independence which would not be acceptable to the central government of Iraq.

\section{The Parliament of Kurdistan-Iraq: A Story of Stable} Instability (1992-2018)

The KRI and its institution's function based on laws legislated by the region itself since 1992. The election law number 1 , of the year 1992 ,iv is the first law legislated by the Kurdistan Parliament and is considered the foundation stone for the government and de-facto state institutions. The election for the first parliamentary term was held in 1992 based on a closed party list electoral system, with a minimum threshold of $7 \%$. Subsequently, through a 2013 amendment, a semi-open party list system of proportional representation was adopted (Kurdistan Parliament, 2013a). This system is still in force and the electors vote for one party list and indicate preference for one candidate within the same party list. Once the election results are announced, each party is allocated seats in proportion to the number of votes received, based on the number of votes for all candidates of the list.

The history of the Kurdistan Parliament-Iraq can be 
described as one of stable instability, given that periods during which the political parties showed intense willingness to move forward have alternated with periods of total inactivity due to instabilities and conflicts. After the first election, the region granted itself autonomous status, and the government's institutions, including the parliament, were established through consensus between the two main political parties, the Kurdistan Democratic Party (KDP) and the Patriotic Union of Kurdistan (PUK). After the elections KDP and PUK joined an alliance with seven other political parties to form a government called a United Government.

Due to the internal instabilities and conflicts elections were not held regularly every four years in the KRI. The election for the second term of the parliament took place in 2005, thirteen years after the first. During this election, due to amendments to the election law, the $7 \%$ threshold was lifted and minorities were granted more quota seats. During the second term a unitary government was formed by all the major political parties.

The election for the third term took place in 2009, at the end of the legally mandated four years. This election took place after a major change in the political atmosphere of the KRI. This was when a significant number of leading PUK members decided to leave the party and found a new political party named as Movement for Change (Gorran). This newly founded party won $24 \%$ of the vote in the 2009 election, while the KDP and PUK alliance won 57\%. Thereafter, the newly founded movement for change decided to remain an opposition party in the parliament. This marked a historical moment, being the first time a political party with such a significant presence decided to remain in opposition.

For the fourth term the election was again held on time, in 2013. None of the winning parties could achieve over $50 \%$ of the seats and therefore a coalition was needed to form the cabinet. After months of discussions, a coalition of all parties and a consensus government was formed. However, the political agreement between the parties did not last long and as a result parliamentary sessions were shut down in October 2015. The dispute was over the length of the presidential term. The second term was supposed to be ended by August 2015, having previously been extended for two years in 2013. The main four party fractions, Gorran, PUK, Islamic Union and Islamic Group, opposed a second extension, while KDP was in favour. The four fractions attempted to hold a parliamentary session and end the term by introducing a new amendment to the presidency law and changing the presidential election procedure from a public vote into an in-session parliamentary vote. However, their attempt to pass this amendment was unsuccessful as they were unable to gather the necessary majority of attendees for the session to be held. A week later, the president of the parliament (who was a Gorran member) was not allowed to enter Erbil, being turned back to his home in Silemani from a checkpoint on his way there. The following day the prime minister, who was from KDP, sacked the ministers in his cabinet from the Gorran movement on the basis that Gorran had violated the agreement upon which the consensus government was built.

The fifth term parliamentary election was held on 30 September 2018. The parties who won seats were: KDP, PUK, Change Movement, Islamic Movement, Islamic Union, Islamic Group, Social Democrats, Labour Party, Armenian, National Council of Chaldean, Assyrian, Ashuri, Turkmen Change and Renovation, Iraqi Turkmen Front and Turkmen Development Party. KDP won 45 seats, PUK came second with 21 seats, and Gorran third with 12.

TABLE 1: Characteristics of the Parliaments of the Kurdistan Region of Iraq (1992-2018) 
Academic Journal of Nawroz University (AJNU), Vol.10, No.4, 2021

\begin{tabular}{|c|c|c|c|c|c|c|c|c|}
\hline Term & Period & $\begin{array}{l}\text { Date of } \\
\text { Elections }\end{array}$ & $\begin{array}{l}\begin{array}{l}\text { Parliament } \\
\text { official } \\
\text { start }\end{array} \\
\end{array}$ & $\begin{array}{l}\text { Parliament } \\
\text { termination }\end{array}$ & $\begin{array}{l}\text { Electoral } \\
\text { System }\end{array}$ & $\begin{array}{l}\text { No. of } \\
\text { seats }\end{array}$ & $\begin{array}{l}\text { Quotas for } \\
\text { Minorities and } \\
\text { Women }\end{array}$ & $\begin{array}{l}\text { Parliamentary } \\
\text { Party Composition }\end{array}$ \\
\hline First & $\begin{array}{l}1992- \\
2005-\end{array}$ & $\begin{array}{l}-19 \\
1992\end{array}$ & $\begin{array}{l}15 \text { July } \\
1992\end{array}$ & $\begin{array}{l}15 \text { January } \\
2005\end{array}$ & $\begin{array}{l}\text { Closed } \\
\text { Party } \\
\text { List } \\
7 \% \\
\text { threshold }\end{array}$ & 105 & $\begin{array}{l}5 \text { seats for Christians } \\
\text { 25\% party } \\
\text { women }\end{array}$ & $\begin{array}{l}\text { PUK, KDP, Purple List } \\
\text { (Created affer elections), Turkmen }\end{array}$ \\
\hline Second & $\begin{array}{l}2005 \\
2009\end{array}$ & $\begin{array}{l}-30 \\
\text { January } \\
2005\end{array}$ & $\begin{array}{l}\text { 05 June } \\
2005\end{array}$ & $\begin{array}{l}07 \\
\text { September } \\
2009\end{array}$ & $\begin{array}{l}\text { Closed } \\
\text { Party } \\
\text { List } \\
\text { No } \\
\text { Threshold }\end{array}$ & 105 & $\begin{array}{l}5 \text { seats for Christians } \\
\text { 25\% party } \\
\text { women }\end{array}$ & $\begin{array}{l}\text { KDP, PUK, KIU, Communist Party of } \\
\text { Kurdistan, YNDK, Turkmen, } \\
\text { Asssrian, Social Democrats, Labour } \\
\text { party, Islamic Group }\end{array}$ \\
\hline Third & $\begin{array}{l}2009 \\
2013\end{array}$ & $\cdot{ }_{2009}^{25}$ July & $\begin{array}{l}20 \text { August } \\
2009\end{array}$ & 30 June 2013 & $\begin{array}{l}\text { Closed } \\
\text { Party } \\
\text { List } \\
\text { No } \\
\text { Threshold }\end{array}$ & 111 & 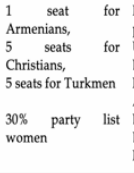 & $\begin{array}{l}\text { KDP, PUK, Change, Communist } \\
\text { party, Islamic Movement, Islamic } \\
\text { Union, Islamic Group, Social } \\
\text { Democrats, Future Party, Rafidayn, } \\
\text { National Council of Chaldean, } \\
\text { Assyrian, Ashuri, Turkmen } \\
\text { Democratic Movement, Turkmen } \\
\text { Brotherhood, Turkmen Reform } \\
\text { Movement }\end{array}$ \\
\hline Fourth & $\begin{array}{l}2013- \\
2018\end{array}$ & 09/21/13 & $\begin{array}{l}\text { 06 } \\
\text { November } \\
2013\end{array}$ & $\begin{array}{l}06 \\
\text { November } \\
2018 \\
\text { (Extended } \\
\text { for One } \\
\text { year) }\end{array}$ & $\begin{array}{l}\text { Open } \\
\text { List } \\
\text { Proportion } \\
\text { al } \\
\text { No } \\
\text { Threshold }\end{array}$ & 111 & 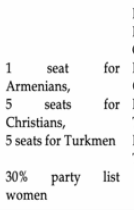 & 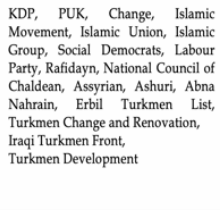 \\
\hline
\end{tabular}

Source: Author's compilation 


\section{KDP-PUK Civil War}

Before moving forward, some consideration needs to be given to historical accounts of the civil war in the early 1990s between the two main political parties, KDP and PUK. On the occasion of the first election in the KRI, these were the only two parties which managed to exceed the $7 \%$ threshold. They achieved almost equal proportions of the vote, with KDP and its coalition partners obtaining $50.8 \%$ of the votes, while PUK with its partners took $49.2 \%$. The impossibility of the two parties sharing power resulted in a civil war, with administration divided between two competing governorates based on the territorial strength of each party, KDP with its base in Erbil and PUK centered in Sulaymaniyah. ${ }^{v}$

So one of the outcomes of the civil war was the legacy of an era known as two administrations. The two administrations had a great impact, to the extent that some of the characteristics and practices of this split system are still visible today. US intervention led to the Washington Peace Agreement which was signed in 1998, whereby the two parties agreed upon a ceasefire. The parliament passed Law Number 16 of 2002 which ratified the ceasefire agreement. However, the agreement was not a complete solution as it did not put an end to the system of two administrations and split government. Throughout this period, the MPs on both sides agreed to several extensions of the first parliamentary term which was supposed to have finished in 1996. In October 2002, the KDP and PUK MPs entered a transitional parliamentary term which lasted until the 2005 election.

The refusal of parliamentarians to be involved is one of the most distinctive features of the civil war. MPs elected on the lists of both parties remained in the chamber in Erbil, the capital city of the KRI, without getting involved in the civil war. For more than a decade, the parliament legislated for both the administrations established in the rival governorates of Erbil and Sulaymaniyah. At the beginning of the civil war, Jawhar Namiq, the president of the Kurdistan Parliament and member of KDP's politburo, released a statement opposing the civil war between the two parties. Together with other MPs from both parties, they participated in public protest against the war. This involved a 103-day sit-in at Panagiri Hall inside the parliament. Although their protest did not put an end to the civil war, it was indicative of the crucial position taken by the MPs, who continued to cooperate and did not interfere in the legislative process.

\section{PARLIAMENTARY CLOSED DOORS AND DISPUTES REGARDING THE PRESIDENCY}

The presidency crisis in the KRI reached its peak in November 2015. The presidential term which should have ended in 2013 was extended for two years by a KDP and PUK majority in the parliament. After two years, the issue was raised in the parliament in 2015 by four main fractions of Gorran, PUK, the Islamic Group and Islamic Union. These four fractions proposed a draft amendment to Law No. 1 (2005) (Kurdistan Parliament, 2005). This move agitated KDP as their leaders interpreted it negatively: (1) the four fractions shouldn't have taken this step unilaterally while being the main components of a consensus government in coalition with the KDP; (2) the focus is mainly on $\mathrm{KDP}^{\prime}$ s leader President Masoud Barzani and assassinating his character rather than focusing on the institution and position of the presidency; (3) the committee to re-draft the constitution was formed to determine the type of government and institutions that should exist in KRI, and what is proposed by the four fractions constitutes interference in their work; (4) the issue should have been discussed by all political parties in the region in order to reach a national agreement over the presidency issue while the region is in a war fighting ISIS terrorists.

Although the parliament was technically in its two months summer legislative break, the four main parties managed to form a quorum and pass the draft 
through its first hearing at the parliamentary session on 23 July 2015. The draft needed a second and final hearing in order to pass into law, and the four fractions declared that they would hold a second session (still during the legislative break) on 19 August 2015 for this purpose. This raised tension among the political parties in the region and divided them into two main fronts, KDP and allies against all the others. As a result, the UN and diplomatic missions in Iraq and KRI got involved, meeting in Erbil on the evening of 18 August, the night before the parliamentary session. The meeting, mediated by the $\mathrm{UN}$ and a significant number of diplomats, brought together all the party leaders and the decision was taken to postpone the second hearing. The following day, the MPs from the four parties who were at the meeting went to the parliament to hold the session, disregarding the agreement. However, attendance did not meet the minimum requirement of $50 \%$ plus which was required to conduct business, and the session was dismissed. Following this, a series of protests occurred in which KDP headquarters and offices in several cities and towns in Silemani province were attacked. This escalated the tension between the parties, and KDP accused Gorran of organizing and directing these attacks. Later, on 12 October, the president of parliament was stopped at Pirdê check point on the Kirkouk-Erbil highway and not allowed to enter Erbil and the parliament. This was followed by the suspension of the Gorran ministers from the cabinet, with the Gorran Movement accused of instigating violence and unrest in the political process in KRI. As a result, the parliament entered a virtual shutdown that lasted more than two years.

The issue of the presidency remained disputed although the legislative council of KRI declared that the president should remain in his position with all his powers intact until the next presidential election was held. This decision was widely criticized and was considered by the opposing political parties, not only
Gorran, to constitute an abandonment of neutrality On 15 September 2017, the parliament was reactivated as part of the agreement among the members of the supreme committee of the referendum who represented the major political parties. Gorran did not take part in the reactivation session and the deputy president from KDP and secretary of parliament from PUK held the session without the president being present. Later, the Gorran fraction returned to the parliamentary sessions but the president sent a resignation letter.

After holding the referendum on 25 September, KRI faced unrest and pressure both internally and from the neighbouring and international communities. In October, Barzani sent a letter to the parliament refusing to stay in his position as president during further extensions. As a consequence of that, the parliament held a session on 29 October in which the powers of the president were divided between the government and the parliament until the next election. However, the next election, which was held on 30 September 2018, took place only for the parliament, while traditionally presidential and parliamentary elections were held at the same time in the KRI. The position remains uncertain, with the main discussions among the political powers referring to making amendments to the law and leaning towards a more purely parliamentary system.

\section{THE PARLIAMENT AND THE INDEPENDENCE REFERENDUM}

On 7 June 2017 Masud Barzani called for an inter-party meeting which a majority of the KRI political parties attended. The outcome was the formation of a committee with a remit to set a date for an independence referendum. The committee unanimously voted for 25 September 2017. The committee also made a commitment to "combine our efforts to reconvene the Kurdistan parliament"(Shanpress, 2017). However, the decision to hold the referendum on that date was criticized, 
principally on the grounds that the parliament is the place to take such fateful decisions, and it was argued that the committee's decision would not be legally binding without the parliament's approval. The two political parties who boycotted the referendum committee were the Movement for Change (Gorran) and the Islamic Group (KIG). They urged that the "top priority is to reconvene parliament" (VOA, 2017). The subsequent committee meeting on 30 June 2017 concluded with a statement that the parliament must be reconvened in two weeks. However, the parliament was only able to hold its reopening session six weeks later, on 15 September 2017, more than two years after its closure, and Gorran and KIG refused to take part in the reconvention session ${ }^{\mathrm{vi}}$. This was particularly problematic because the president and the secretary of the presidential board were from Gorran and KIG, constituting two out of three members of the board. Nevertheless, the session was held and led by the deputy president of the parliament from KDP, with 73 of the 111 MPs present at the session. The first item on the agenda was nomination of a secretary for the parliament's presidency. A member was nominated by the PUK fraction and was unanimously approved. The next item was a resolution which delegated (Kurdistan Parliament, 2014a) the Kurdistan Independent Higher Elections and Referendum Commission (IHERC, 2017) ${ }^{\text {vii }}$ to hold a referendum in the KRI. viii

\section{STRUCTURE, FUNCTIONS AND POWERS OF}

\section{THE KURDISTAN PARLIAMENT-IRAQ}

The formal structure of the Kurdistan Parliament-Iraq resembles the classic model of parliamentary structures in Western democracies, with the addition of progressive elements in terms of a legally enforceable gender quota and a quota for religious and ethnic minorities.

The first two parliament terms consisted of 105 seats in the chamber, and the name was also the National Council of Kurdistan-Iraq according to Law No. 1 (1992). In 2009, the law was amended (Kurdistan
Parliament, 2009) and the name changed to Kurdistan Parliament-Iraq. The same amendment increased the number of seats to 111, among which 11 seats are allocated to minorities, consisting of five seats for Turkmen, five seats for Assyrians and Chaldeans, and one seat for Armenians. This amendment also lowered the minimum age of candidates from 30 to 25 . At the same time, the minimum quota for women was increased from $25 \%$ to $30 \%$.

The parliament sits for two sessions each year, spring and winter, each with a duration of four months. There is a two months legislative break when members focus on matters related to oversight. Parliamentary presidency consists of a president, deputy president and secretary of the parliament. The three members of the presidency are elected in a secret vote inside the chamber. The president of parliament calls for sessions and extraordinary sessions. An extraordinary session can also be requested from the presidency by a minimum of $25 \%$ of MPs.

\section{MINORITY QUOTA MANIPULATION}

The KRI is home to religious, ethnic and cultural diversity. Along with the Kurds, other ethnic groups such as Chaldo-Assyrians, Turkmen, Armenians and Arabs live in the KRI. In addition to the Sunni and Shia divisions of Islam, there are other ancient religious groups, such as Christians, Yeazidi, Kakaís, Shabaks, Zoroastrians and Sabis. The Sunni Muslim Kurds are the majority in the region and they hold most of the power and positions. The institutional arrangements of the KR-I grant ethnic minorities a legal right to be securely represented in the parliament under the quota system described in the previous section. However, the dominant political parties in the KRI are frequently accused of manipulating the minority quota for their own interest. This is done through their support for certain candidates who are usually members of their party from within the minorities. This issue needs closer examination in order to understand more clearly whether this is the case and, if so, how the 
manipulation works and how substantial a problem it is. There is also high demand by the represented and misrepresented parties in the government for the election law (Law 1 (1992) amended) to be amended again to ensure that minorities obtain representation.

Views vary regarding the existing quota system from both inside and outside the minority communities. A conference on the quota system and the representation of the minorities concludes that the minority parties and their politicians main concern is the manipulation of the existing quota seats by the ruling or the majority parties, and that their demand is an amendment of a law that guarantees the participation of the minorities with no interference (OTT, 2016). Meanwhile, the ruling parties believe that the existing law and the quota system guarantees the political participation and secures 11 seats for the minorities.

\section{PARLIAMENTARY COMMITTEES}

There are two types of committee in the Kurdistan Parliament-Iraq, permanent and temporary. The permanent committees discuss and prepare reports on draft proposals for the laws relevant to the committee. The number of permanent committees increased from 19 to 22 following an amendment to the parliamentary bylaw in 2014 (Kurdistan Parliament, 2014b) but this was decreased to 15 (Table 1) following a further amendment in 2018 (Kurdistan Parliament, 2018). Their function is to have an oversight role in keeping the government accountable. For this reason, the committees are created to reflect the existing ministries, so that each of the current 15 committees have a ministry (or more than one) to scrutinize. They are expected to play an active role in legislation especially regarding the draft laws related to the remit of the committee.

The temporary committees are formed when needed to consider a particular situation or issue; various parliamentarians are appointed to cooperate on a specific issue and report the result of their discussions to the presidency of parliament and other parliamentarians. In order for a temporary committee to be established its proposed formation has to receive the vote of a majority of MPs.

Each member of parliament, except for the presidential committee of parliament, is obliged to be a member of at least one committee and at most two. Selection of committee members is one of the very first tasks undertaken by the parliament after elections. The committees consist of a minimum of five members and a maximum of eleven. Each committee has a presidency consisting of a president, deputy and coordinator. The committee presidency is usually decided upon by a consensus between political fractions of parliament and their members mostly follow the agreement during voting for the presidency of the committees.

Table 2: Parliamentary Committees, As of Fifth Parliamentary Term

1. Committee of legal affairs

2. Committee of finance and economic affairs

3. Committee of Peshmerga, interior, security and local councils

4. Committee of agriculture and irrigation

5. Committee of education, higher education and scientific affairs

6. Committee of health, environment and consumers' rights

7. Committee of social affairs, children and family

8. Committee of municipalities, transportation, reconstruction, resettlement and investment.

9. Committee of rituals and religious affairs

10. Committee of martyrs, genocide affected and political prisoners

11. Committee of industry, trade, energy and natural resources

12. Committee of culture, civil society, sports and youth

13. Committee of integrity, parliament affairs and complaints

14. Committee of relations and diaspora affairs

15. Committee of areas of Kurdistan outside Kurdistani administration (disputed areas)

10. Functions and Powers of the Parliament: Representation, Legislation and Government Oversight

According to the relevant laws in Kurdistan - the election law, presidency law, Kurdistan Parliament's bylaws ${ }^{i x}$ - the three main functions and powers of the Kurdish parliament are as follows: representation, 
legislation and government oversight (see table 2).

These functions are interrelated and have the same scope: to represent the constituency in decisionmaking, and this can be seen as being the main function of MPs. KRI is based on a social tribal system and traditionally individuals appeal to the structures of the tribe in order to pursue their rights. Bearing in mind that parliamentary representation had never existed in the region before 1992, the parliamentary institution has slowly started to shift tribal practices towards a modern approach to the application and execution of individual rights. However, a large proportion of the rural population is linked to their MP through their tribe and through the mediation and clientelism of the tribal leaders. In this way, the MPs can be perceived both as representatives of the tribal system and representatives of the individuals who bypass the traditional tribal arrangements. $x$ This arrangement also plays a decisive role in the election process, being the funnel that determines the number of votes taken by the candidates and parties. In other words, the closer a candidate is to the tribal constituency, the higher the probability that they will have popular support and be elected.

When it comes to gender and minority representation, there is a formal descriptive representation present in the parliament. However, given the lack of experience of the exercise of democracy, along with the intricate tribal-political party system, it is rather intuitive that the main decisions are taken within and between political parties. These quotas are, more often than not, a formal concession to give an appearance of conscionable arrangements, rather than the emanation of a genuine democratic practice.

Table 3: Three main functions of the Parliament of Kurdistan - Iraq

\begin{tabular}{ll}
\hline Representation & $\begin{array}{l}\text { Representation of the constituency. } \\
\text { Debating the major issues of the day. }\end{array}$ \\
\hline Legislation & $\begin{array}{l}\text { Drafting and examining proposals for new laws. } \\
\text { Passing laws. Amendment of laws }\end{array}$
\end{tabular}

\begin{tabular}{ll}
\hline & Scrutinize government policy and \\
administration. & Check and challenge the work of the \\
Government. & Check and approve Government spending \\
Government & (budget). \\
Provide for the formation of a government, the & designation of the candidate for the office of \\
& prime minister to form a cabinet. \\
Granting and taking of votes of confidence in \\
the cabinet or a minister.
\end{tabular}

\section{LEGISLATION: LEGISLATIVE PROCESS}

Drafts of laws and resolutions are proposed by, and through an initiative of, either at least 10 members of parliament, the Presidency of Kurdistan Region or the Council of Ministers. Every draft is proposed to the presidency of the unicameral parliament of Kurdistan. Then the draft is distributed among all the MPs. After that the draft is put on the agenda of the plenary session for a first hearing. After the initial proposal, the draft laws have to be agreed by the parliamentary presidency before being put on the sessional agenda for the first hearing. Having passed the first hearing, the proposed draft is directed by the presidency of the parliament to the relevant committee, which issues a report following discussion at meeting at which the majority of the members of committee have to be present.

The relevant committee will be designated by the president of the parliament to prepare the report on the draft in cooperation with the committee of legal affairs within 10 days. Some drafts are prioritized by the president, and in these cases the report shall be ready within five days. The report will be distributed again among all the MPs to be discussed in the next session, the second hearing. The draft is discussed article by article and the new proposals and suggestions for each article or sub article are voted on by the MPs. Finally there is a vote on the amended draft, and if it is passed it then goes to the president for their signature. Within 10 days of this the newly passed legislation is sent to the president, who may propose a revision of part or the whole legislation and send it back to the 
parliament, and in such cases the decision of the parliament is the final one.

All the sessions are open and accessible to the public through online live-stream, TV, or other means of communication such as Facebook livestream. A request can be made by $25 \%$ or more of the MPs for there to be a private exclusive session with no live coverage, and this needs to be agreed by majority vote, otherwise it will be held with the usual public accessibility. This is usually done when there are sensitive issues to be discussed. ${ }^{x i}$ There is an area from which members of the public can watch plenary sessions from an specified place for the guests overlooking the plenary. A full record of debate in all sessions is registered and the minutes are gathered continuously and even the printed versions are delivered to the MPs and are also available at the parliamentary library where it is easily accessible by the public.

12. AN EXAMPLE: THE APPROVAL OF THE YEARLY BUDGET

A most important law for any parliament is the annual budget. The process by which this law is brought into being is described here, as an indicator of the established rules and routines involved in the legislative procedures of the Kurdistan ParliamentIraq. The proposed budget is prepared by government and the annual accounts are also due to be submitted to the parliament before the end of each year. ${ }^{\text {xii }}$ The budget proposal is given priority status, and when it reaches to parliament, the finance committee is designated to prepare their report on the draft and bring it to the session for further discussions. The committee's report must be prepared no later than three days from the date on which the proposal arrived. All the committees have the right to give their comments and insights in accordance with their remits. The report is distributed among the MPs in order to be studied during the two days before the session. Fractions usually discuss the budget proposal among themselves, in accordance with their party position. The session on the budget has two stages, first discussions on the expenditure and then on the proposed budget. Parliament also has its own budget, and that is added to the overall budget of KRI. The proposal is then voted on by parliamentarians and requires a simple majority vote to pass.

\section{LEGISLATIVE PRODUCTION}

During the first two years of the parliament, the various laws passed covered the establishment of the institutions of the Kurdistan Regional Government. With 38 laws and 64 resolutions, these two years were the most active ones. Even though in 1994 the two main parties entered a civil war, the parliament and the MPs decided to continue to function. The civil war influenced the legislative process but it did not come to a complete halt. In 2005, the second parliament was elected and since then parliamentary elections have been held every four years and legislation continues to go through (see graph 1). The legislative process was blocked in the first months of the fourth term, causing a legislative void that was replaced by the Council of Ministers through decrees.

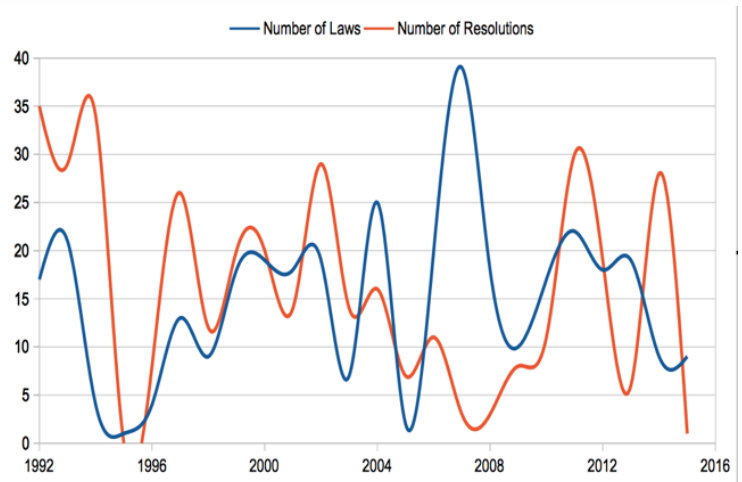

Graph 1: Number of laws and resolutions passed by the Parliament of the Kurdistan Regional Government in the period 1992-2015

\section{PARTY COHESION AND VOTING BEHAVIOUR}

The parliament consists of various fractions that represent political parties. Members of each fraction operate mainly in a cohesive fashion, particularly with regard to voting on legislation. Each fraction has a presidency unit. For instance, the presidency of KDP fraction consists of the president of the fraction, deputy 
president, coordinator and spokesperson. The fractions abide by party political discipline and this is secured through the presidency of fractions, which are in continuous contact with their political parties over the issues being discussed in the parliament. There are also frequent meetings between the members of fractions and the leadership of their political party. The members are usually asked by the presidency of the fraction to be aware of the need to act cohesively in order to achieve the party goals with regard to specific legislation. There have been a few cases when members have voted against their party, but this usually ends with the interference of the fraction's presidency or party leaders to resolve the issue.

\section{THE FUNCTION OF OVERSIGHT AND RELATIONS WITH THE COUNCIL OF MINISTERS}

The oversight function of the Parliament of Kurdistan - Iraq has three stages: parliamentary questioning, parliamentary scrutiny and vote of confidence. Every member of parliament has the right to address written or oral questions to the executive power through the presidency of the parliament (Article 62). The questions are to be responded to by the prime minister of by any related member of the Council of Ministers or the addressed minister within a period that does not exceed 15 days from the date that the question is asked (Article 65). The response to the question is disclosed in the next parliamentary session and if the questioner is satisfied with the response or is not present and no one else follows it up, the issue is considered closed (Article 66). Otherwise, if the response is not found satisfactory or if the Council of Ministers does not respond in time, the next stage is the parliamentary scrutiny of the government. Parliamentary scrutiny involves a request for an explanation addressed by the parliament to the executive (Article 67 and 68). The scrutinized member of the Council of Ministers usually appears in the next session and gives an explanation regarding the issue concerned (Article 69,
2). At the end of the session the executive member's explanation is put to the vote. If the majority vote goes in favor of the explanation the case is considered finished. Otherwise, if two thirds or more of the votes are cast against the explanation, the member of the executive considers is censured through a vote of no confidence (Article 70).

\section{THE RELATIONSHIP BETWEEN THE PARLIAMENT AND THE PRESIDENT OF KURDISTAN}

The relationship between the parliament and the president of KRI is set out in 12 articles of Law Number 1 (2005), the Presidency Law (Kurdistan Parliament, 2005). After being elected by direct vote, the President takes the oath of office in the Parliament. As part of the legislative process, the laws adopted in the parliament require the approval of the president within fifteen days. If the president has a disagreement with a part or the whole of a proposed law, s/he sends it back to parliament for reconsideration. However, the president has no power of veto. The final decision on whether to accept the president's concerns and amend the law accordingly or pass it unamended rests with the parliament. In practice, so far neither the parliament nor the president have challenged each other during the law-making process. The only source of dispute between some of the parliamentary political parties and the president was focused on the amendment of the presidency law. This dispute was serious enough to lead to the blockage of the parliament, which is still the case at the time of Writing. xiv

\section{PARLIAMENT AND JUDICIAL SYSTEMS}

Unlike established institutional arrangements in modern political systems, in KRI there is no institution that resembles the constitutional court which is a feature of modern democracies, and an institution which would check on the constitutionality of the legislation adapted by the Kurdistan Parliament. The only formal constitutional court is in Baghdad, and 
that checks the compliance of KRI law with the Iraqi constitution. This court has been contacted with regard to KRI legislation only once, in 2009 , on the initiative of a leader of the Change Movement. The question regarded the passing of law by the Kurdistan Parliament when its term had concluded. The response of the constitutional court of Iraq was that this was a legal act provided the term had been extended by law. It is important to mention the existence of the Shura Council within the Ministry of Justice, which in some cases is asked for interpretations of law, even if this interpretation is neither formalized nor binding. ${ }^{\mathrm{xv}}$

\section{RELATIONS WITH THE IRAQI AND FOREIGN PARLIAMENTS}

The Kurdistan Parliament-Iraq has formalized and developing relations with both the Iraqi federal parliament (Iraqi Council of Representatives) and many foreign parliaments.

Of the 328 seats on the Iraqi Council of Representatives, Kurdistan is represented by between 60 and 65 . The relationship between the two parliaments is limited to the constitutional rights of the Kurdistan region. This includes issues such as budgetary projects or even international treaties and agreements. The MPs from Kurdistan Region to the Iraqi parliament are the people mostly involved in carrying out this relationship. The Kurdistan Parliament is fully authorized, according to the constitution, to accept, refuse or amend any legislation passed by the Iraqi Council of Representatives insofar as its adoption in KRG is concerned.

The Kurdistan Parliament is a member of a number of inter-parliamentary unions and parliamentary friendship groups. The relationship with the parliaments of other countries is a direct one. International parliaments are also aware that the way to contact the Kurdistan Parliament is not through the Iraqi Council of Representatives. It receives and sends official delegations from and to parliaments around the world.

\section{SOME CONCLUSIONS}

There are a few conclusions that can be drawn from this overview of the development of the functions of the Parliament of Kurdistan - Iraq. The first is that this case constitutes a unique occurrence in the entire history of the Kurdish population in the Middle East and might provide an example to be replicated in an unknown future by other Kurdish groups living under the flag of other nation states. Since the very first days of its foundation, the Kurdistan Parliament had been functioning as a parliament for a de facto independent state, with formal arrangements and the functions of an independent state. This is reinforced also by the fact that both the parliament and its body of legislative decisions were considered to be valid and continued to be recognized after the change of regime in Baghdad. Secondly, the Iraqi Council of Representatives is still a work under construction, having incorporated some elements of a classic parliament, expressed in the formalization of rules and processes. However, much more institutional development has to occur in order for these rules and procedures to be internalized both by political elites and the broad population. The very fact of having its own parliament is a novelty for the population. Intense friction between ambitions of modernization and embedded structures of the tribal system is taking place. This is a process that will require more than a few decades, and any comparison with parliaments elsewhere are unhelpful.

A third conclusion is that each of the four parliamentary terms can be seen as a variety of exercise with the aim being to learn self-government and consolidate power over a territory with an undecided future. The last three terms of the parliament, 2005, 2009 and 2013, were the result of different types of consensus that kept it functioning actively. As soon as the consensus was broken, the parliament faced blockage and it ground to a halt. From this point of view, the first term of the Iraqi Kurdistan Parliament represented an exception: during the first term in 1992 
there was a fifty-fifty agreement between the main two parties, KDP and PUK. When the two parties entered a civil war in 1994 the parliament decided not to be a part of this and continued its job. Despite the fact that the civil war resulted in two district governments operating at the same time while based in two different cities - KDP-run Erbil and PUK-run Sulaymaniyah this division was not reflected in the institution of the parliament, which continued to function almost as normal.

A fourth conclusion is that just having the formal prerogatives of an independent, fully fledged parliament is not enough for it to function as one. The activity and results of the activity of the Parliament of Kurdistan-Iraq naturally reflect the dynamics and divisions of the society that it represents: the parliament had periods of great activity alternating with periods of inactivity. The institution had frozen periods caused by broken agreements and lack of consensus among the main political parties (KDP and PUK) and their territorial constituencies (Erbil and Duhok vs. Sulaymaniyah). Differently put, the only times when the parliament has been functioning efficiently were those when the main political parties maintained common agreement and were at peace with each other.

A final conclusion that can be drawn is that, generally speaking, the Kurdistan Parliament can be seen as a piece of a broader puzzle of the region. Despite its ups and downs, the parliament has gained sufficient legitimacy inside the territory and plenty of recognition abroad; whenever and whatever its decisions, these are legally applied and binding for the entire KRI. Thus, all the decisions adopted so far have led to substantial economic independence and quite a firm level of control over the territory and its social groups. It is just a matter of time and awaits a window of opportunity for political independence to be officially discussed and declared by this institution. Whenever this decision will be made, this parliament will have sufficient legislative legacy and popular support to continue its existence.

Further research is needed to obtain a better understanding of the dynamics and factors at play in the development of this institution. Qualitative and quantitative data are essential in order to be able to further explore the efficiency and effectiveness of the parliament. However, given the geopolitical circumstances, the very fact of its continuing existence is already a measurable result.

\section{REFERENCES}

1. Constitute Project (2021). "Iraq's Constitution of 2005." Available https:// www.constituteproject.org/constitution/Iraq_ 2005.pdf?lang=en

2. IHERC (2017). "Primary Results." Available at: http:/ / www.khec.krd/pdf/173082892017_english\%20 2.pdf

3. Kurdistan National Assembly (1992). Elections Law Iraq, No. 1 for the year 1992 (UNAMI unofficial translation). Available at: https:/ / www.google.com/url?sa=t\&rct=j\&q=\&esrc=s \&source=web\&cd=1\&ved $=2$ ahUKEwjavZv1 $1 \times 9 j m A h U F$ rosKHUHICyQQFjAAegQIBxAK\&url=http $\% 3 \mathrm{~A} \% 2 \mathrm{~F} \%$ 2Fgjpi.org\%2Fwp-

content $\% 2$ Fuploads $\% 2$ Fconsolidated-amendment-toelectoral-law-of-the-kip-unami-unoffical-translationfinal-annotated.doc\&usg=AOvVaw3RGHpC9a9bgeMELuvlHxn

4. Kurdistan Parliament (1992). Yasayi Jimare 1, 1992, Yasayi Helbijardinî Kurdistan [Law No. 1, 1992, Kurdistan Elections Law]. Available at: http:/ / perleman.org/files/articles/010315072126.pdf

5. Kurdistan Parliament (2009). Yasayi Jimare 2, 2009, Hemwari Çiwaremi Yasayi Helbijardinî Encumeni Nishtimani Kurdistan [Law No. 2, 2009, Kurdistan Elections Law Fourth Amendment]. Available at:

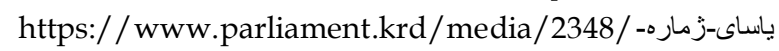

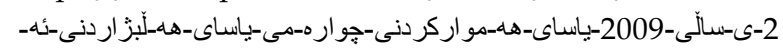

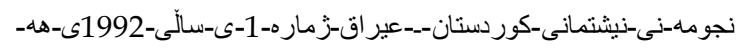
مواركراو.pdf

6. Kurdistan Parliament (2005). Yasayi Jimare 1 î sali 2005, Yasayi Serokayeti Herêmî Kurdistan [Law No. 1, 2005, Kurdistan Presidency Law]. Available at: http:/ / perleman.org/files/articles/101207105105.pdf

7. Kurdistan Parliament (2014a). Yasayi Jimare 4, 2014, Yasayi Komisiyonî Serbexoyi Helbijardin û Rapirsî [Law No. 4, 2014, Election and Referendum Independent Commission Law]. Available at: http:/ / perleman.org/files/articles/020914010617.pdf

8. Kurdistan Parliament (2014b). Biryari Jimare 7, 2014, 
Hemwari Hestemi Peyrewi Nawxoy perleman [Resolution No. 7, 2014, Eighth Amendment of Kurdistan Parliament's Bylaw]. Available at: https:// بwww.parliament.krd/business/resolutions / بر

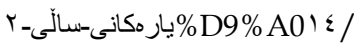

9. Kurdistan Parliament (2018). Peyrewi Nawxoyi Perlemani Kurdistan, [Kurdistan Parliament's Bylaw]. Available at:

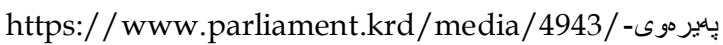

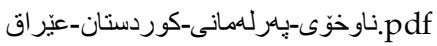

10. Open Think Tank. (2018, August 16). The Quota System: Limiting or Securing the Representation of Ethnic and Religious Minorities in the Kurdistan Region of Iraq. Open Think Tank OPEN DEBATES 5 Report and Recommendations Comments.

i The Iraqi interim government was created on 28 June 2004 to govern the country until the drafting of a new constitution. It was replaced by the Iraqi transitional government on 3 May 2005.

ii For more regarding the arrangements of the Iraqi Constitution, see: John McGarry and Brendan O'Leary (2005). "Iraq's Constitution of 2005: Liberal consociation as political prescription", International Journal of Constitutional Law; Nathan J. Brown (2005). The Final Draft of the Iraqi Constitution: Analysis and Commentary Endowment for International Peace; Dodge, Toby (2005). Iraq's Future: The Aftermath of Regime Change (Adelphi Papers).

iii The provisions in the Iraqi Constitution regarding the Region of Kurdistan are as follows:

Article 116: The federal system in the Republic of Iraq is made up of a decentralized capital, regions, and governorates, as well as local administrations.

Article 117: First: This Constitution, upon coming into force, shall recognize the region of Kurdistan, along with its existing authorities, as a federal region.

Article 121: First: The regional powers shall have the right to exercise executive, legislative, and judicial powers in accordance with this Constitution, except for those authorities stipulated in the exclusive authorities of the federal government.

Second: In case of contradiction between regional and national legislation in respect to a matter outside the exclusive authorities of the federal government, the regional power shall have the right to amend the application of the national legislation within that region.

Third: Regions and governorates shall be allocated an equitable share of the national revenues sufficient to discharge their responsibilities and duties, but having regard to their resources, needs, and the percentage of their population.

Fourth: Offices for the regions and governorates shall be established in embassies and diplomatic missions, in order to follow cultural, social, and developmental affairs. https:/ / otto.krd/ open-debates-5-report-andrecommendations/.

11. Taha, M. Y. (2020). Media and Politics in Kurdistan: How politics and media are locked in an embrace. Lexington Books. Shanpress (2017) http:/ / www.shanpress.com/Wtardetails.aspx?jimare= $\underline{814}$

12. $\mathrm{VOA}$

https://www.dengiamerika.com/a/kurdistan/389225 1.html

\section{Footnotes}

Fifth: The regional government shall be responsible for all the administrative requirements of the region, particularly the establishment and organization of the internal security forces for the region such as police, security forces, and guards of the region.

Article 141: Legislation enacted in the region of Kurdistan since 1992 shall remain in force, and decisions issued by the government of the region of Kurdistan, including court decisions and contracts, shall be considered valid unless they are amended or annulled pursuant to the laws of the region of Kurdistan by the competent entity in the region, provided that they do not contradict with the Constitution.

(The full Iraqi Constitution is available at: http:/ / www.wipo.int/wipolex/en/text.jsp?file_id=230001)

iv The law was drafted by a committee consisting of representatives of the Kurdistan Front and then approved by the Kurdistan Front leadership. On 19 May 1992, about one million voters participated in parliamentary elections in the three governorates of the areas under Kurdish control in the northern part of Iraq.

$v$ The post-election negotiations led the two parties to form a coalition government and this power-sharing agreement is known as the Government of Fifty-Fifty. The initial purpose of this coalition was to create a balance of power and it was intended to put the two parties in a position of agreement. This 'fifty-fifty' was an attempt to convince the two main parties to accept power sharing, starting with the formation of a cabinet with almost $50 \%$ of ministers from each. The deputy ministers were also granted exactly equal powers of a minister in practice. These deputies were intended to preserve the balance of power because if the minister was KDP the deputy had to be PUK and vice versa. This power sharing was not without problems, especially for the leadership of the two parties, who had spent at least the last five decades of their history as rebels in the mountains. Therefore, on one hand, power-sharing and reaching an agreement to form a government was crucial at that time to maintain peace between the two parties, on the other hand, 
this type of power-sharing did not function effectively and proved to be something of a blockage to decision making. For instance, when a KDP minister has a PUK deputy with the same powers and authority, or vice versa, neither of them would be able to easily make decisions, especially when there was already a background of disagreement between the two parties. Instantly, conflicts arose. Rapidly growing disputes over matters such as revenue shares arose. The Government of Fifty-Fifty survived for less than two years, after which both parties stepped into a civil war. The war between PUK and KDP divided the region into two administrative territories, one under the control of PUK with Sulaymaniyah as its capital city while Erbil remained under the control of KDP as the centre for the territories which they administered. KDP established its regime in Erbil in 1996 and shortly afterwards, in January 1997, PUK established itself in Sulaymaniyah.

vi Gorran movement's ministers were sacked from the government and the president of the parliament who was from Gorran block was not allowed back to the parliament's sessions. These two issues were among many other unfinished businesses between Gorran and the main ruling party (KDP) that emerged by July 2015 and continued till the end of the fourth term of the parliament.

vii The IHERC was established according to Law No. 4 (2014). The drafting of the law commenced after the KRI President's address to parliament on 3 July 2017, when he requested a committee to be formed to consider the referendum. In less than a month (Kurdistan Parliament, 2014) it was legislated in a popular vote in the parliament and the commission was established after that.

viii The parliament delegated the elections and referendum commission to hold the referendum at its first meeting after it was reconvened. Details at: https:// kurdistantv.net/ar/node/1030

ix During the fourth term of the parliament the bylaw was amended and the new rules apply from the fifth term onward.

$x$ The tribal aspect of Kurdish society is among the most curious hangovers from past social constructions. There are no studies related to the relationship between politics and tribes in the Kurdistan Region of Iraq. For this reason, any account of parliamentary representation cannot be informative enough, as there are many more hidden ties and relationships between this social structure and political institutions needing to be explored.

xi Usually MPs request an exclusive session in cases related to security, because of the sensitivity of the topic.

xii There are large differences between the law and its practical application here. For instance, since the start of the fourth term of the parliament in 2013, there have been no budget proposals by cabinet to parliament. Some of the main reasons for this relate to: the financial crises; the war against ISIS; the disputes between the region and Baghdad that led the central government to impose budget and salary cuts on the region; the fall in oil prices.

xiii This graph was computed by the authors, based on data available on the Parliament website: www.parliament.krd

xiv The current president, Mustafa Barzani, the leader of the KDP, was elected in 2005 and reelected in 2009, and his term was coming to an end in August 2013. In the last session of the third term of the parliament on 30 June 2013, the presidency law was amended to allow his term to be extended the for another two years, though this was not extendable for a second time. Two years afterwards, on 15 June 2015, two months before the termination of the extension, the president asked the Kurdistan electoral commission to make the necessary preparation to hold a presidential election. According to Law No. 1 (1992), amendment 4 (2009), which is called the Kurdistan Elections Law, the president shall request the electoral commission to hold elections at least two months before the termination of parliament or presidential term.

After this the commission declared their inability to hold elections in a session in front of parliament, justifying with the following factors:

1) War against terrorism: being at war and having a frontline of more than $1000 \mathrm{~km}$, with IS terrorist groups close to the regional borders.

2) Economic deficiency: Budget and wage cuts imposed by the central government since January 2014 , and a dramatic downfall in oil prices. At the same time, receiving nearly 1.8 million refugees and IDPs.

3) Logistic deficiency: The commission is newly established, and the proposed structure has not been put in place due to the lack of budgeting by the government. In order to resolve the issue, some political powers proposed to amend the presidency law and have the president elected in the parliament. Meanwhile, a committee was formed by the parliament and designated to re-draft the constitution of Kurdistan. This committee was made up of representatives from all the political parties. KDP and its allies proposed to wait for the drafting committee of the constitution to decide on the political system: whether direct or indirect vote, and whether a parliamentary, presidential, mixed or any other political system would be proposed.

xv For more details about the judiciary system in KRI, see the Global Justice Program: Iraq (2009). “The Judiciary and the Law in the Kurdistan Region of Iraq" at: http://gjpi.org/2009/08/14/the-judiciary-and-the-law-inthe-kurdistan-region-of-iraq/; and United Nations Development Programme Iraq (2003). "Promoting Rule of Law in the Kurdistan Region of Iraq through a Modern, Efficient and Accountable Justice Sector" at: https://info.undp.org/docs/pdc/Documents/IRQ/RoL\%2 0Annual $\% 20$ Rep $\% 202013 \% 20$ V2\%20with $\% 20$ Output $2,3$. doc $\underline{x}$ 